\title{
Geology of the Dan field and the Danish North Sea
}

\author{
BY \\ F. B. Childs and P. E. C. Reed \\ DANSK SAMMENDRAG \\ De geologiske forhold i Dan-feltet \\ og den danske del af Nordsøen
}

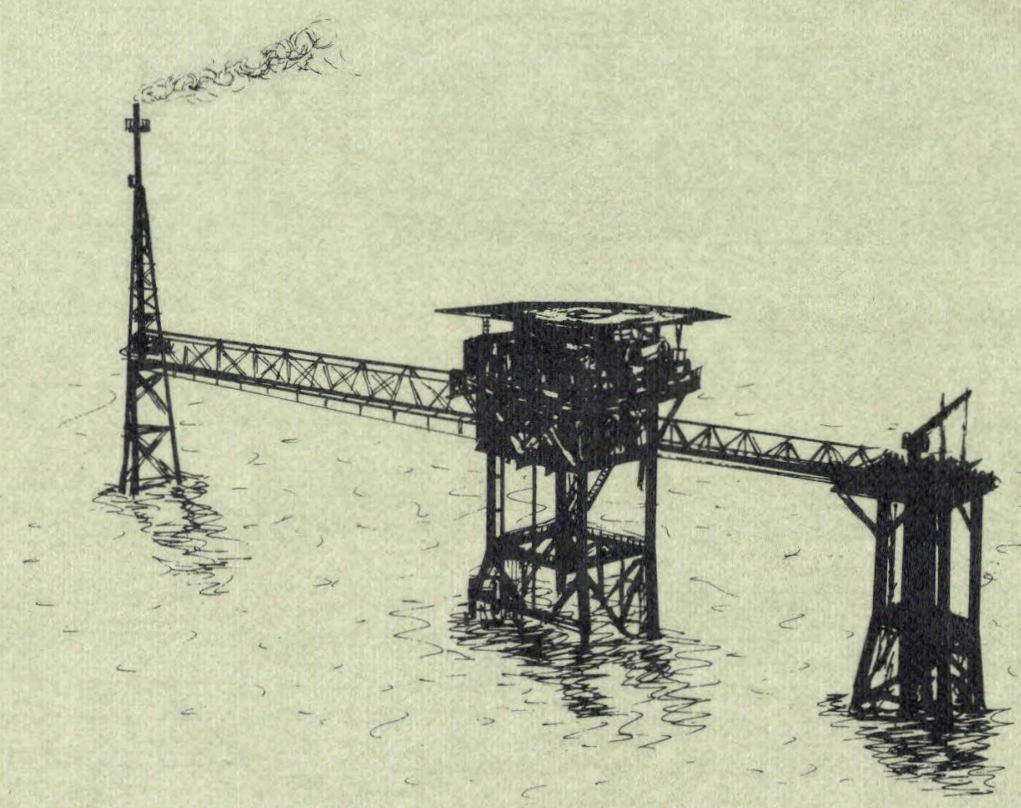


Danmarks Geologiske Undersøgelse. III. Række. Nr. 43

Geological Survey of Denmark. III. Series. No. 43

\section{Geology of the Dan field and the Danish North Sea}

By

F. B. Childs and P. E. C. Reed

Dansk sammendrag:

De geologiske forhold i Dan-feltet

og den danske del af Nordsøen

I kommission hos C. A. Reitzels Forlag

København 1975 
D. G. U. III. rk. nr. 43

er sat med Fotosats Times

og trykt i offset i 1200 eksemplarer

hos Andelsbogtrykkeriet i Odense

Bogen er trykt på ekstraglittet 262, $125 \mathrm{~g}$

fra a/s De forenede Papirfabrikker

ISBN 8742106397

Date of publication: January, 16th 1975

Forfatterne til nærværende publikation tilhører begge Gulf Oil

Company's geologstab. F. B. Childs er Regional Geologist Europe for Gulf Oil Company - Eastern Hemisphere, med sæde i London.

P. E. C. Reeds arbejder for tiden i Nigeria.

Vignetten på omslaget er tegnet af Kirsten Andersen 


\section{Contents}

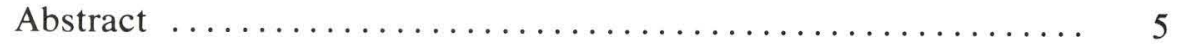

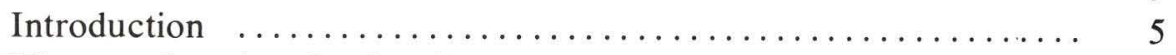

History of exploration in offshore Denmark $\ldots \ldots \ldots \ldots \ldots \ldots .7$

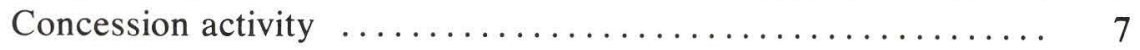

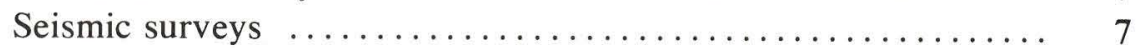

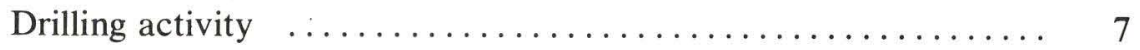

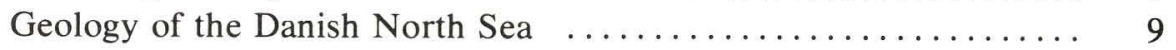

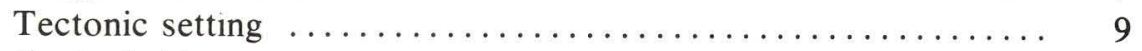

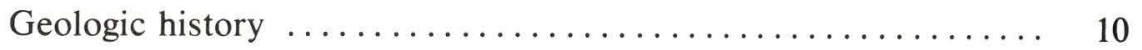

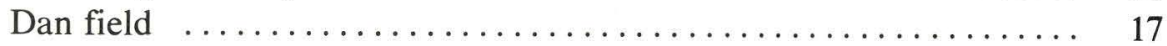

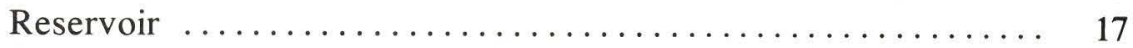

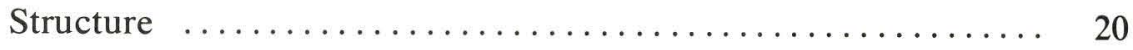

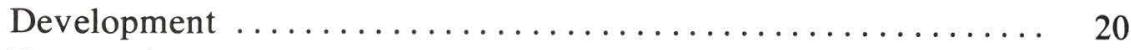

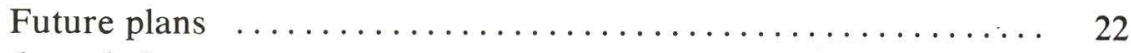

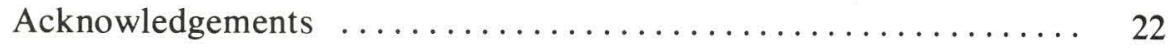

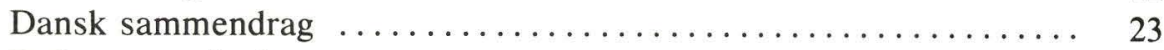

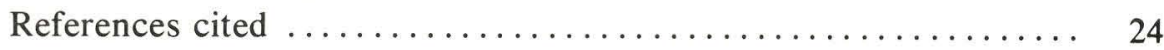




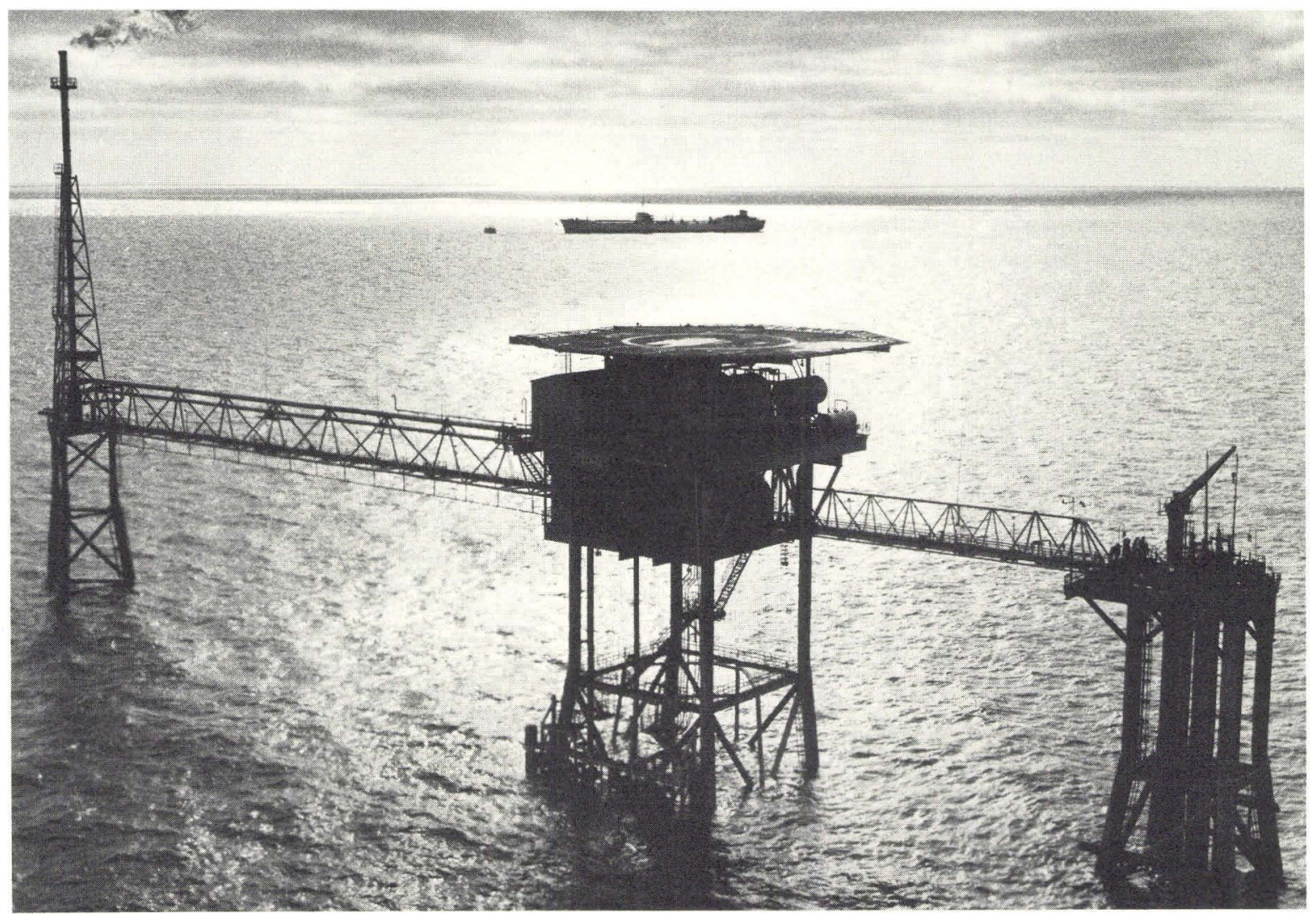

The production reconstructions on the Dan field.

A. P. Møller copyright

To the left the flare structure, to the middle the production platform and to the right the drilling platform. In the background is seen the oiltanker Marie Mærsk « in a distance of $1.5 \mathrm{~km}$ from the production structure. 


\section{Abstract}

The Dan field was discovered in 1971 by the Dansk Undergrunds Consortium's fifteenth offshore wildcat, which encountered oil and gas in Maestrichtian and Danian chalk at the subsea depth of 5790 - 6565 feet. Production of some 800 BOPD from each of five wells began in July 1972.

The field lies on the eastern flank of the North Sea Tertiary basin and near the axis of the Central Graben, a deep trough filled with a thick sequence of Permian to Cretaceous sediments. Upper Cretaceous-Danian chalk at the top of the sequence provides the reservoir for several further hydrocarbon accumulations in offshore Denmark. Geochemical studies indicate that deeper Upper Jurassic marine shales are the probable source beds for these accumulations.

The Dan field is a halokinetically induced domal anticline. The chalk reservoir has an average porosity and permeability of $28 \%$ and 0.5 millidarcy, respectively. The solution GOR is $600 \mathrm{cu}$. $\mathrm{ft} . / \mathrm{bbl}$ and the crude oil is $30^{\circ}$ API with low sulphur content (0.29\%).

\section{Introduction}

The Dan field, named after the first king of Denmark, lies in the southwestern portion of the Danish North Sea in a water depth of 140 feet, approximately 205 kilometers west of the port of Esbjerg and 170 kilometers southeast of the Norwegian Ekofisk oil field (Figure 1). Discovered in May, 1971, by the Dansk Nords $\varnothing$ M-1x well, which encountered a total hydrocarbon column of approximately 750 feet in Lower Tertiary (Danian)Upper Cretaceous chalk, Dan was brought on stream in July 1972, and currently produces approximately 4500 BOPD. 


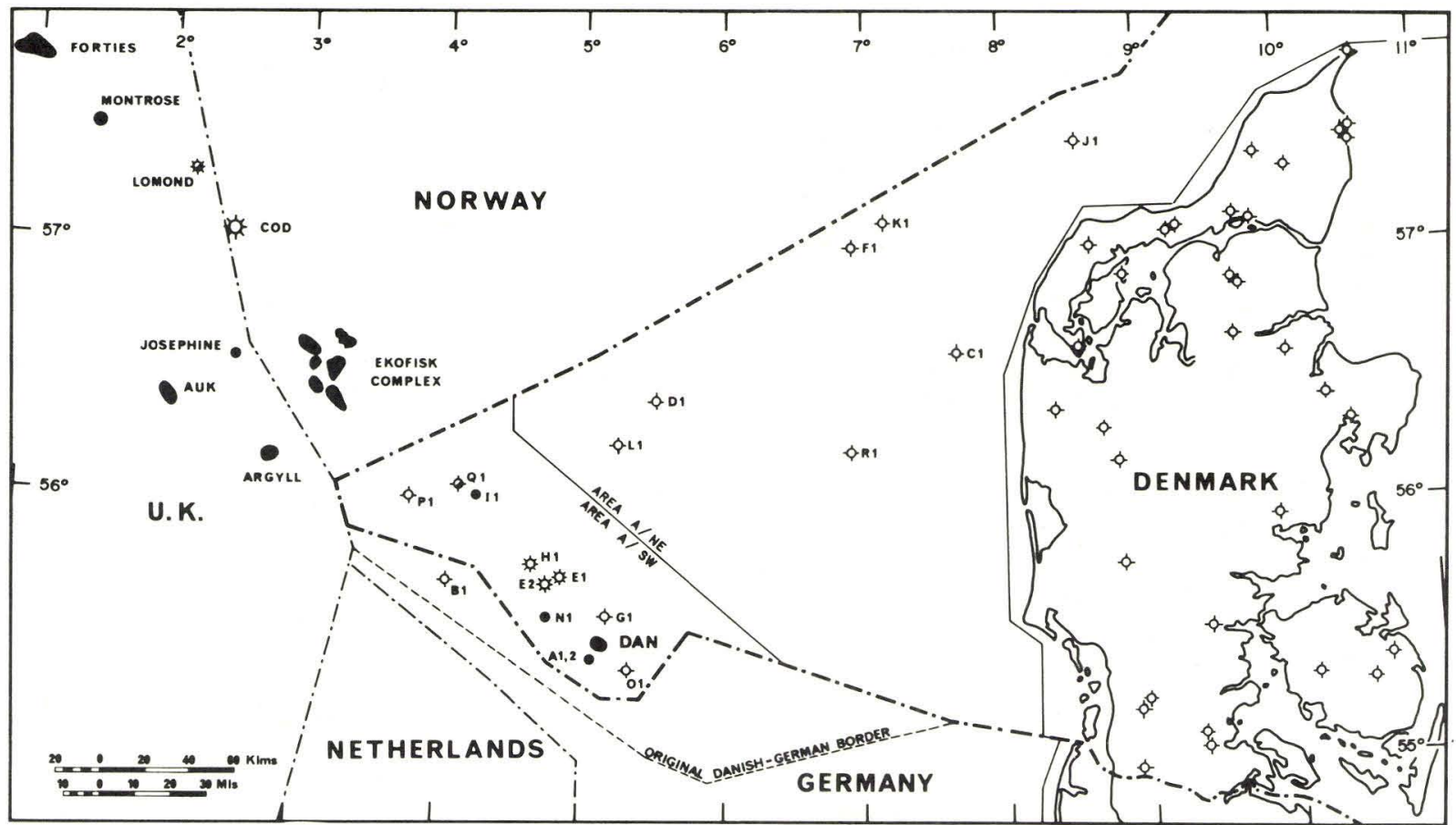

Figure 1. Concession boundaries and status of exploration wells, offshore Denmark. 


\section{History of exploration in offshore Denmark}

\section{Concession activity}

In 1962 the concession for exploration and recovery of oil and gas in the onshore and inland waters of Denmark was granted to the Danish company, A. P. Møller. To carry out the work, the Dansk Undergrunds Consortium (DUC) was formed, with A. P. Møller as concessionaire, Gulf as operator, and Shell as assisting party.

In 1963 the concession area was extended to include the Danish continental shelf. A few years later, Chevron and Texaco joined the joint venture group in the continental shelf only. In 1970 Gulf withdrew from a portion of the shelf, retaining only the area referred to as »Area A-Southwest « and Chevron became operator within the portion that Gulf relinquished, referred to as »Area A-Northeast «.

As a result of decisions reached within the International Court of Justice in 1969, a border treaty between Denmark and Germany was signed in 1971 whereby Denmark released its claim to a certain portion of the continental shelf. Prior to the border treaty, only one well, Dansk Nordsø B-1x, had been drilled in the area now belonging to Germany.

\section{Seismic surveys}

The first seismic survey in the Danish North Sea was conducted in 1963. Using 50-pound dynamite charges, 8700 line miles of seismic reflection data had been acquired by the end of 1967. CDP multiplicity varied from $100 \%$ to $600 \%$. Mapping of good reflections representing the top and bottom of the Lower Tertiary-Upper Cretaceous chalk and the top of Permian (Zechstein) salt outlined several large structural closures.

From 1968 to the present, an additional 4500 line miles of seismic reflection data have been acquired. By using air guns, aquaflex, and aquapulse as energy sources, and increasing the CDP coverage to $1200 \%$ to $4800 \%$, significant improvements in data quality have been achieved. These improvements have increased the reliability of correlation of deep events and have led to delineation of more subtle structures.

Positioning throughout all seismic surveys was carried out with the Decca system and/or satellite navigation.

\section{Drilling activity}

The first offshore well in Denmark, the Dansk Nordsø A-1x, was drilled in 1966 on a large Zechstein salt dome in the southwestern part of the Da- 


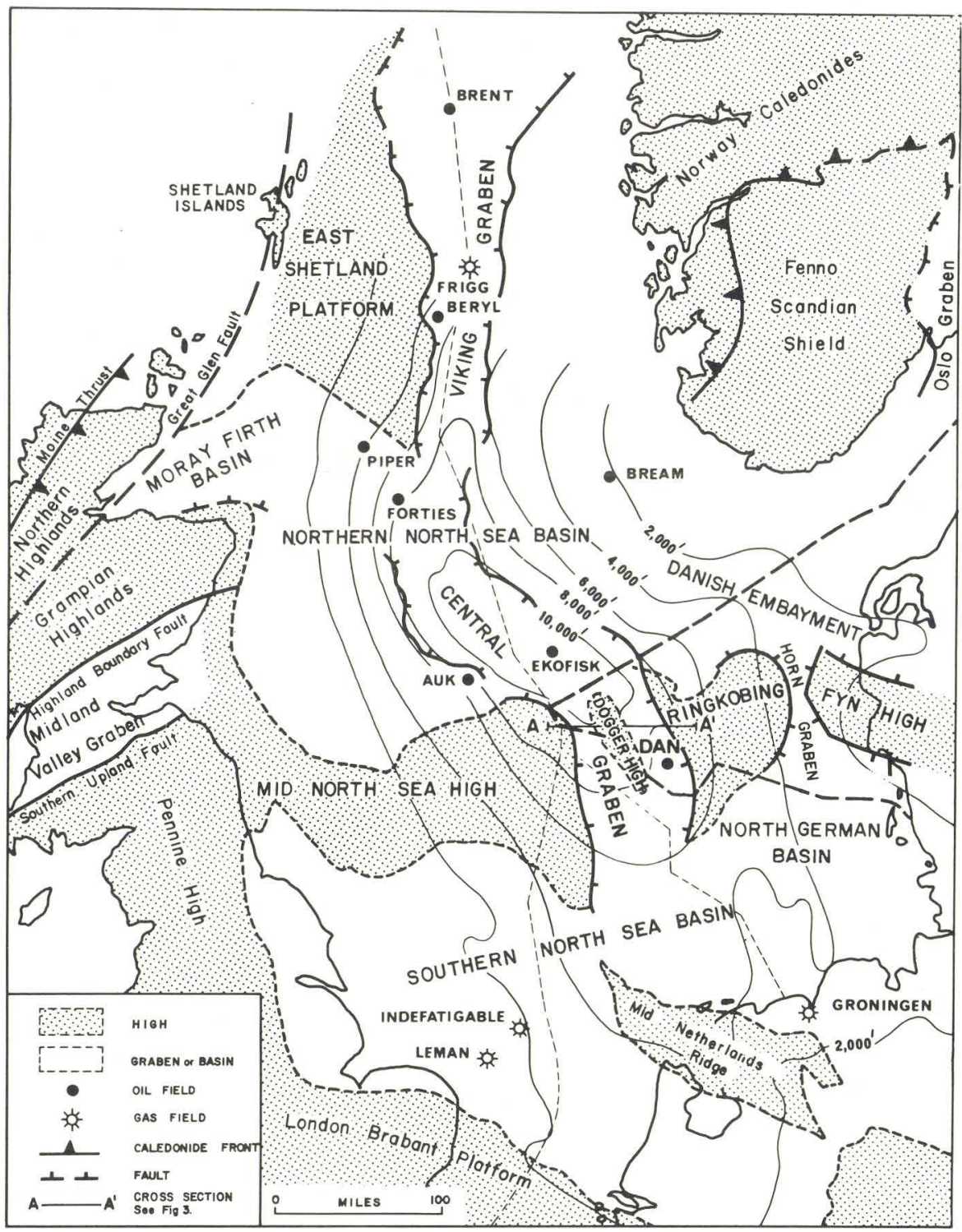

Figure 2. Geotectonic map of the North Sea, showing structural contours on Base Tertiary. (Modified after Heybroek et al., 1967, and unpublished map of the P.E.S.G.B. Committee on North Sea Nomenclature). 
nish shelf and found oil and gas in non-commercial quantities in Lower Paleocene (Danian) chalk. This well was the first to establish the presence of oil in the North Sea.

Up to the present time, 21 additional exploratory wells have been drilled in the Danish North Sea. Beyond the Dan field discovery, the occurrence of oil and gas has been established in four and three wells respectively. The proven hydrocarbon accumulations are all in the southwestern area and, with the exception of the Q-1x and M-8x wells, in the Danian-Upper Cretaceous chalk. Oil shows in the Q-1x and M-8x were from a formation stratigraphically below the chalk.

\section{Geology of the Danish North Sea}

\section{Tectonic setting}

The Danish continental shelf lies on the eastern flank of the North Sea Tertiary Basin, an elongate epeirogenic downwarp filled with over 10,000 feet of sediments along its depocenter (Figure 2). Below the Tertiary Basin, the tectonic framework of offshore Denmark is dominated by a major horst complex, the Ringkøbing-Fyn High, which extends westward from onshore Denmark toward the Mid North Sea High. These two structural highs are separated by a deep trough, termed the North Sea Central Graben, trending NW-SE through the western portion of offshore Denmark and filled with a thick section of Permian to Cretaceous sediments. The Dogger High is an uplifted fault block within the Central Graben (Figure 3). Other major Permo-Mesozoic sedimentary basins: the Danish Embayment and the Northwest German Basin (Sorgenfrei, 1964) flank the Ringkøbing-Fyn High to the north and south, respectively, and are connected by the Horn Graben.

These major tectonic elements were clearly established by Late Permian time and continued to control sediment distribution into the Cretaceous (Figure 4). Normal faulting along the graben margins was particularly pronounced during the Triassic and Late Jurassic. By Late Cretaceous time, however, differential subsidence had ceased, and both basins and highs were blanketed by chalky limestones. The central North Sea subsided as a single basin during the Tertiary.

Dan field and other hydrocarbon discoveries in offshore Denmark are confined to the Central Graben area. 


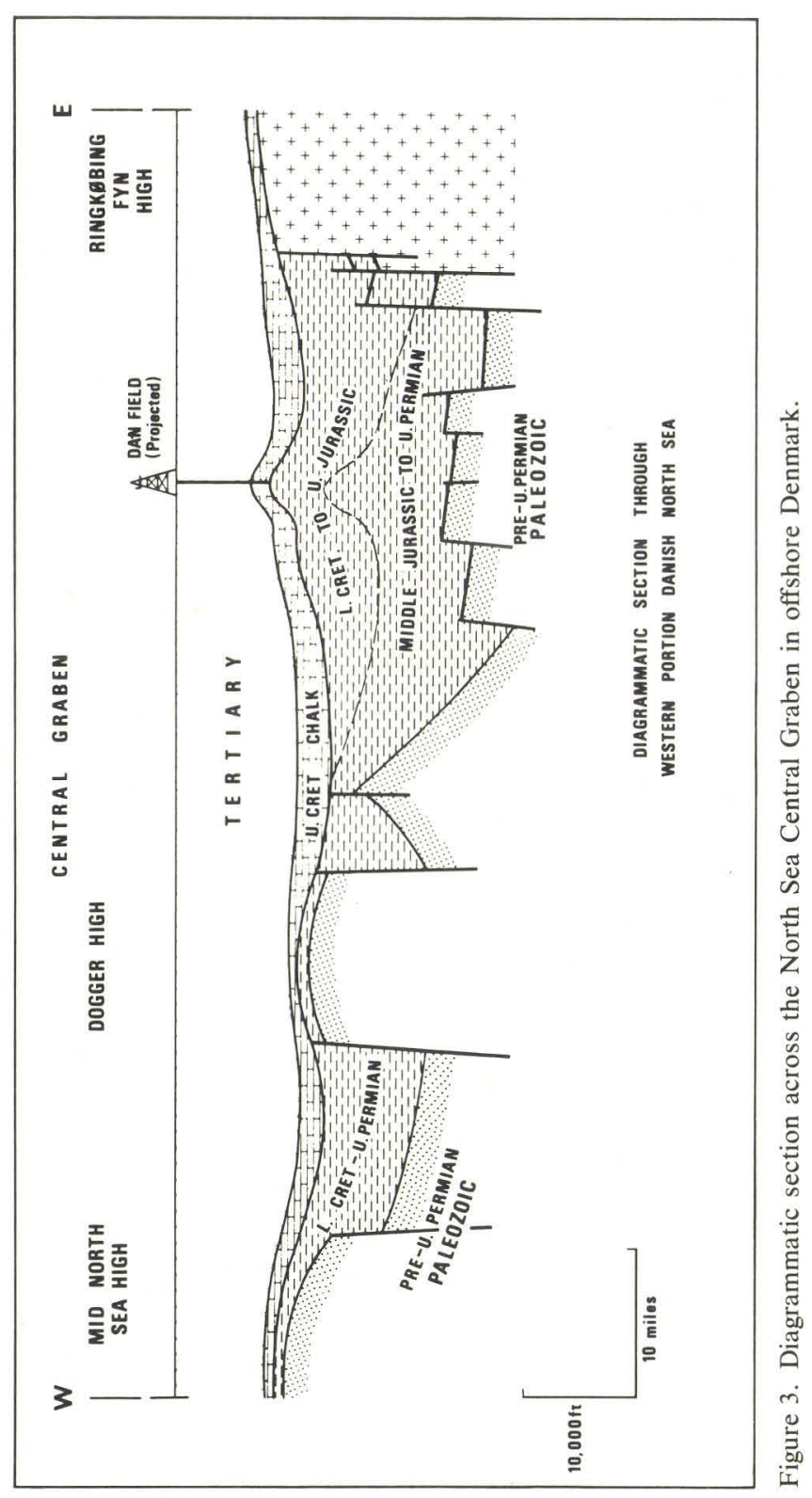

\section{Geologic history}

Pre-Permian

During the Devonian and Carboniferous, offshore Denmark was part of the emergent, low-lying foreland flanking the elevated Caledonian mountain 
belt which extended from Scotland through the northern North Sea to Norway (Ziegler, 1973). Local incursions of the sea onto this foreland during the Carboniferous, however, are indicated by the presence of a few hundred feet of Visean-Namurian shales, sands, and limestones unconformably overlying slightly metamorphosed Lower Paleozoic shales in the Central Graben area.

\section{Permian}

Differential subsidence across the Ringkøbing-Fyn-Dogger-Mid North Sea High trend first occurred during early Permian, separating the North Sea into two intracratonic basins.

As in the southern North Sea (Glennie, 1972), red-bed sequences of shale and sand (Rotliegendes) were deposited under arid desert conditions in the Central Graben and Danish Embayment. Weathered volcanic basalt flows are characteristic of the lower Rotliegendes encountered in offshore Denmark wells.

During Late Permian, continued subsidence resulted in marine transgression. While thin sequences of anhydrite, carbonates, and minor shales accumulated on the upper flanks of the Ringkøbing-Fyn and Dogger Highs, thick salt was deposited in the Northern and Southern North Sea Basins and in the Central Graben. Later halokinesis of this salt, beginning in the Late Triassic, has caused local thickness variations of Jurassic, Cretaceous, and Tertiary sediments.

\section{Triassic}

With retreat of the Zechstein seas at the end of the Permian, an arid continental depositional regime again prevailed in the central North Sea, and thick sequences of Triassic red-beds were Jeposited in the Danish Embayment and the Central Graben. Seismic reflection data suggest that the Horn Graben was developed mainly during the Triassic.

Predominantly sandy near the base, the composite Triassic section known from drilling in offshore Denmark becomes increasingly shaly upwards, indicating a gradual reduction in relief of the sediment-source areas. During the Late Triassic, saline lakes were periodically developed, as shown by the presence of beds of evaporitic carbonates, anhydrite, and, in the Central Graben, salt. Locally, thicker Triassic salt beds show evidence of halokinetic movement.

Latest Triassic (Rhaetian) time was marked by deposition of gray sands and shales in lagoonal environments, heralding the return of marine conditions which have prevailed in the Central Graben to the present time. 


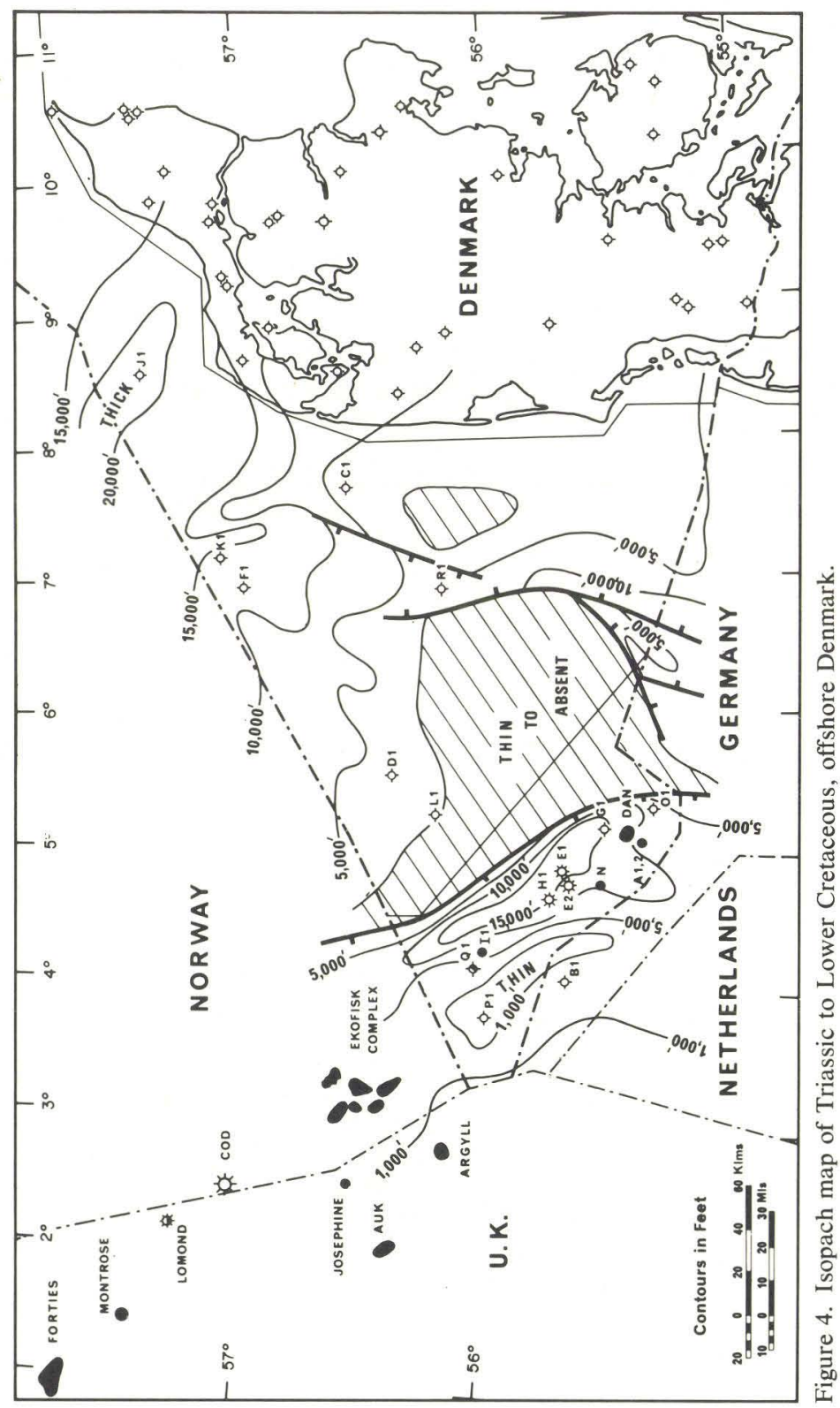

Jurassic

By Early Jurassic time, fully marine conditions were established throughout the basinal areas, where Lower Jurassic sediments are represented by dark gray to grayish-brown shales with minor quantities of very fine-grained sandstone and siltstone. These shallow-marine deposits are succeeded by 

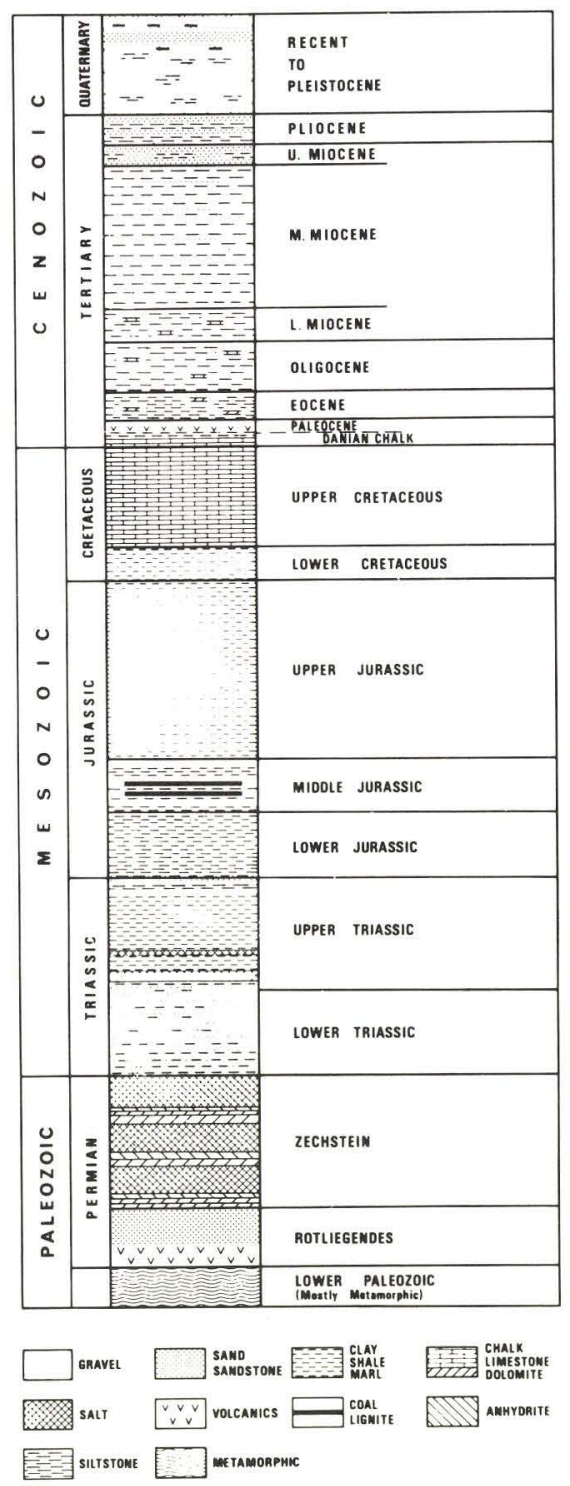

Figure 5. Composite statigraphic column, offshore Denmark.

Middle Jurassic shales with interbeds of sandstone and coal, indicative of marine regression and deltaic to paludal deposition.

A marked change in the rate bf subsidence and depositional environment occurred during the Late Jurassic in the Central Graben. In this region. Middle Jurassic deltaic deposits are abruptly overlain by several thousand 
feet of dark gray to black carbonaceous shales, occasionally with very thin limestone interbeds. Lithology and presence of radiolaria indicate a deepwater, restricted-marine environment of deposition.

The rapid subsidence and sediment accumulation, accompanied by faulting and minor folding along the eastern margin of the graben and on the flanks of the Dogger High, may have occurred in response to the main opening of the Atlantic ocean basin (Hallam, 1971).

The Danish Embayment contains a much thinner section of Upper Jurassic shale, predominantly medium to light gray and slightly silty and sandy but becoming black to dark gray near the top.

\section{Cretaceous}

Deposition of dark gray shales, commonly pyritic, continued into the Early Cretaceous in areas of thick Upper Jurassic sediments. However, sublittoral microfaunas indicate shallowing conditions and gradual cessation of differential uplift across the Ringkøbing-Fyn and Dogger Highs. During the Aptian and Albian, these highs were gradually onlapped by reddish brown to brownish gray, marly shales grading upwards into dolomite and limestone.

By Late Cretaceous time, most of the Dogger and Ringkøbing-Fyn Highs were submerged below sea-level and had ceased to shed clastic sediments into the adjacent lows. As a result, thick accumulations of clean, white to light gray, chalky limestone were deposited throughout offshore Denmark under quiet, clear-water, open-marine conditions. Over 3,000 feet thick in some parts of the Central Graben area, the chalk thins to less than 1,000 feet where it onlaps and overlaps the Ringkøbing-Fyn Highs (Figure 6). Pronounced thickness changes across Zechstein salt domes attest to active halokinetic movement during the Late Cretaceous.

\section{Tertiary}

Chalk deposition continued in offshore Denmark in the Early Paleocene (Danian), although reworked Maestrichtian faunas in the Danian chalk attest to local uplift and erosion, probably related to salt doming. Gradually deepening waters in Late Danian time terminated chalk deposition, and led to a resumption of clastic sedimentation.

The post-Danian history of the central North Sea is one of gradual epeirogenic subsidence and basin-filling (Figure 3). The Paleocene to Oligocene sequence is almost entirely shale, with a thin interval of volcanic tuff in uppermost Paleocene and basal Eocene and thin limestone and dolomite stringers in the overlying Eocene and Oligocene sections. Microfaunal as- 


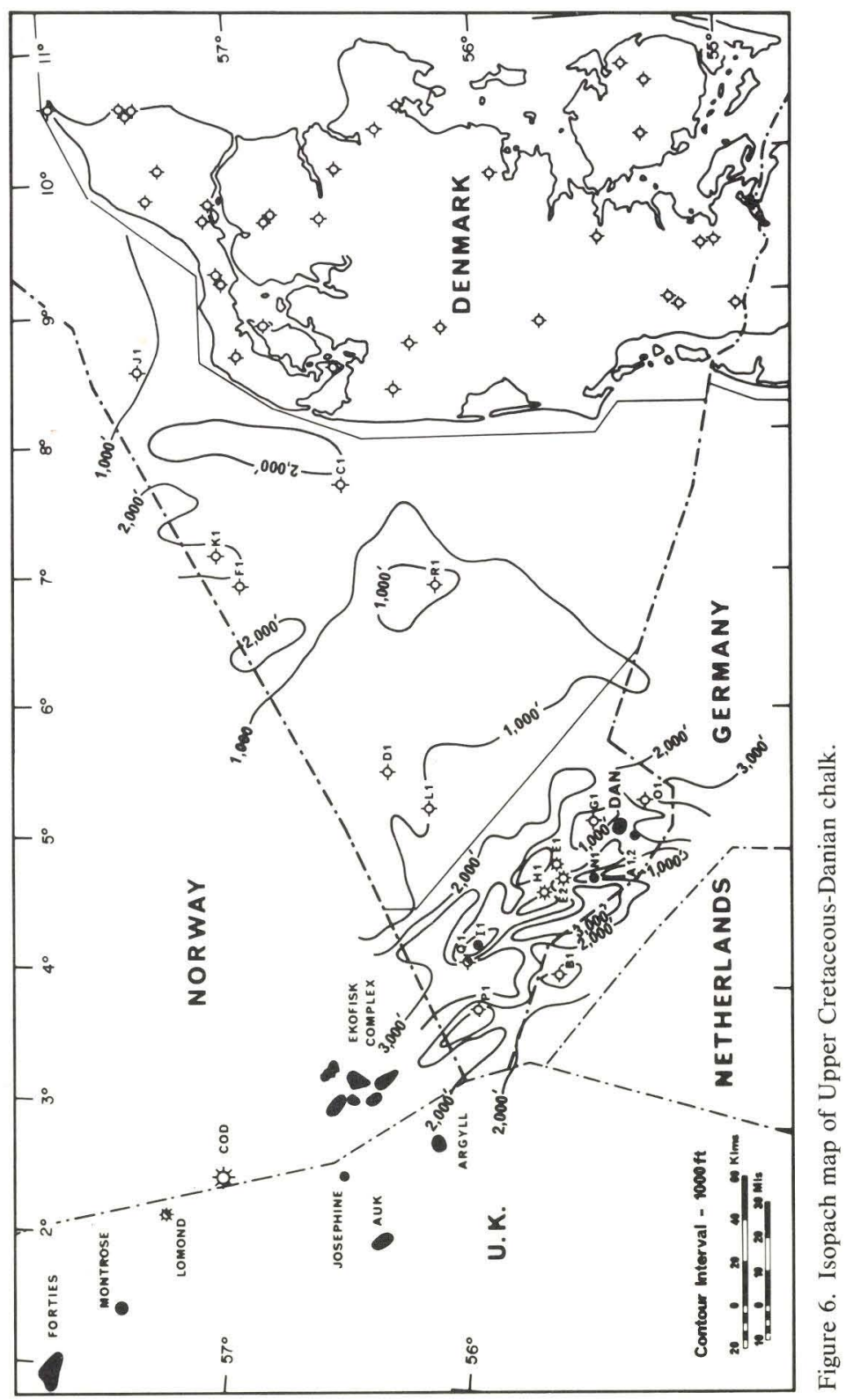

semblages indicate bathyal to outer shelf conditions throughout Early Tertiary time.

Gradually shallowing shelf conditions are indicated for the Miocene to Pliocene interval, characterized by shales and clays in the Lower Miocene, grading upwards into interbedded clay and shale in the Middle Miocene, 
which in turn grades up into fine to coarse-grained sand, with subordinate clay and shell interbeds, in the Upper Miocene to Pliocene section.

\section{Quaternary}

Quaternary deposits in offshore Denmark consist of fine to coarse-grained sands and shell beds with occasional lenses of lignite and soft gray to graybrown clays. 


\section{Dan field}

The stratigraphic column penetrated by the Dan field discovery well consists of 1,900 feet of Upper Miocene to Recent sand and clay, 3,890 feet of Lower Paleocene to Middle Miocene clay and shale, 960 feet of massive Upper Cretaceous to Danian chalk, 210 feet of Lower Cretaceous carbonates and shales, and over 350 feet of Upper Jurassic shales. The hydrocarbon column lies in the Danian-Upper Cretaceous chalk unit, immediately overlain by Early Paleocene shales which provide the reservoir seal. Geochemical characterization of the organic matter in formations above and below the chalk indicates that the underlying Upper Jurassic shales were the source beds of the oil.

\section{Reservoir}

The stratigraphy, lithology, and petrophysical characteristics of the Dan field reservoir are best known from the M-1x well, which was continuously cored through most of the hydrocarbon-bearing interval (Figure 7). On the basis of nannofossils, the uppermost 130 feet of chalk are dated as Danian and the underlying 800 feet as Maestrichtian. The lowest Danian nannofossil zone identified in offshore Denmark is missing in this well, indicating an unconformity at the Danian-Maestrichtian contact. The thick Maestrichtian chalk conformably overlies 30 feet of Campanian and possibly older Late Cretaceous chalk which rests, possibly unconformably, on Lower Cretaceous (Albian to Valanginian) dolomite, limestone, and arenaceous shales.

Megascopically, the chalk is firm to hard, white at the base of the section, becoming cream to buff and tan in the middle and upper Maestrichtian, and white to grayish-white in the uppermost Maestrichtian and the Danian. These colour variations are attributable, in part, to variable oil-staining. Highly inclined to vertical fractures, generally intersecting and sometimes crossed by low-angle fractures, are common in the Maestrichtian interval but rare and of very restricted extent in the Danian chalk. Similarly, stylolites are abundant in the Maestrichtian below 6,000 feet, but virtually absent from the uppermost Maestrichtian and Danian sections. Thin shale laminae, occasionally pyritic, occur at several horizons throughout the 


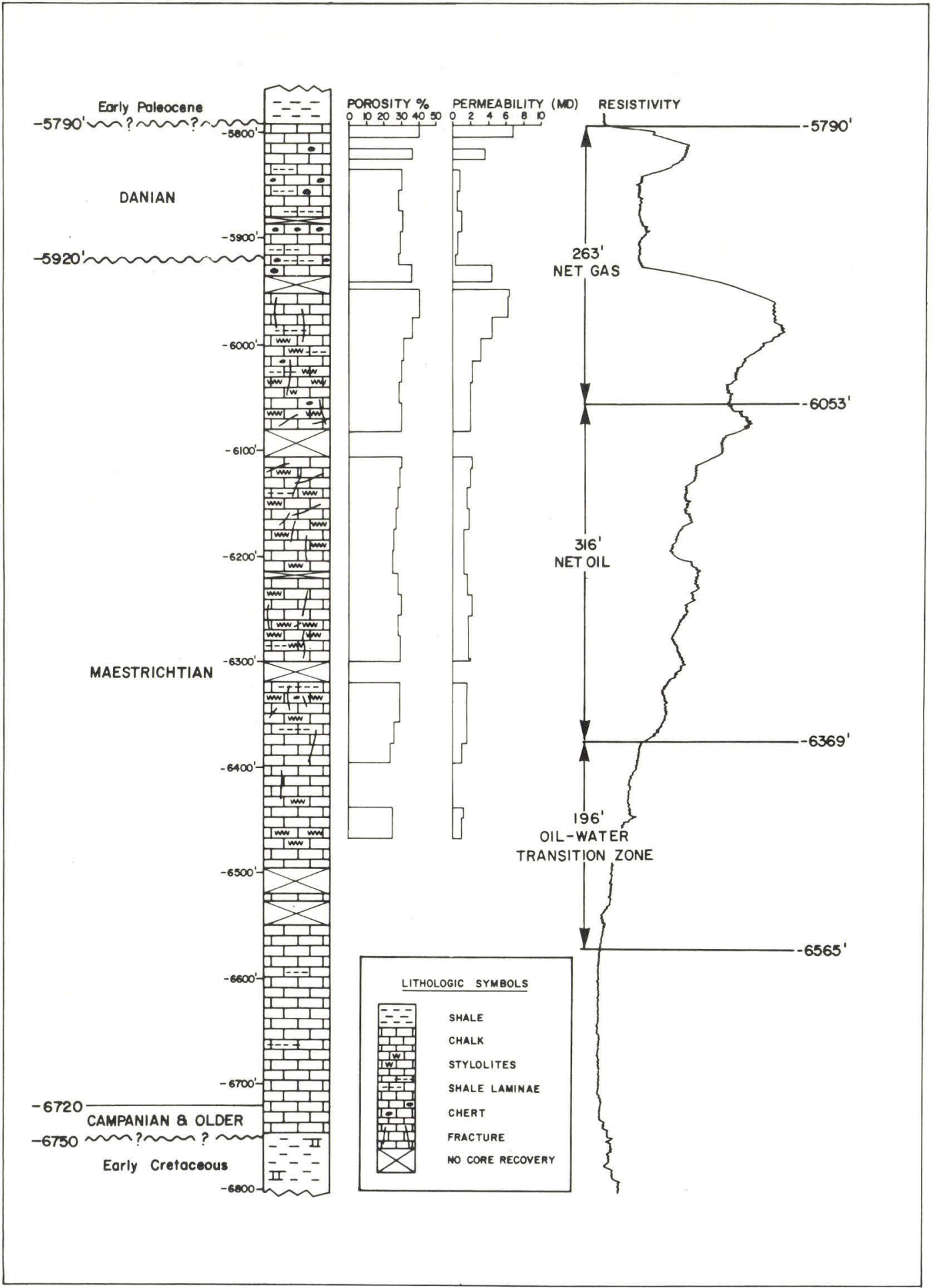

Figure 7. The Dan field reservoir at M-1x well. Porosity and permeability based on 486 plug analyses and averaged over 10 -foot intervals. 
chalk. Chert is common in the Danian and the upper part of the Maestrichtian.

In thin-section, the chalk is classified mostly as fine-grained, mud-supported biomicrites, grading through fossiliferous micrites to micrites containing virtually no skeletal debris. Recognizable skeletal grains, generally constituting $5-10 \%$ of the rock but occasionally up to $25 \%$, include »calcispheres« (Oligostegina), planktonic foraminifera, sponge spicules, radiolaria, echinoid plates and spines, ostracodes, benthonic foraminifera, and rare molluscan and bryozoan fragments. Whereas calcispheres are the dominant skeletal grains throughout the Maestrichtian and older chalk, planktonic foraminifera are the dominant skeletal material in the Danian chalk.

Although porosity is not evident in thin-sections, scanning electron microscopy shows moderate to good, primary interparticle porosity within the micritic matrix, the greater part of which appears to consist of coccolith debris. Individual coccolith plates, generally about 5 microns in size, are subordinate to plate fragments, which appear as minute euhedral to subhedral crystals of rhombohedral calcite with an average size of less than 1 micron. Minor welding of the crystals is common, probably a result of incipient pressure-solution at particle contacts. Secondary cement is only rarely observed.

Core analysis measurements, averaged over 10 -foot intervals, show that most of the chalk section in the M-1x well has porosities of $25-30 \%$ and permeabilities less than 2 millidarcies. However, significantly higher porosities (30-40\%) and permeabilities (3-7 millidarcies) occur at 2 levels, one at the top of the Danian chalk and one immediately below the DanianMaestrichtian contact. In both cases, these higher porosity-permeability zones have abrupt upper boundaries and graditional lower boundaries. Pore size distribution analyses by the mercury injection method tend to suggest that the dominant pore size in these zones may be somewhat higher than that in the intervening and underlying sections, i.e., 1 micron versus less than 0.85 micron. The origin of these higher porosity-permeability zones is still not clear, but it is tentatively suggested that they represent secondary leaching at Early and Late Danian unconformities.

As shown in Figure 7, the hydrocarbon column at Dan field can be subdivided into a gas cap 263 feet thick, an oil zone 316 feet thick, and an oilwater transition zone 196 feet thick. Although measured core permeabilities through the oil zone in the M-1x well show an average permeability of about 2 millidarcies, effective permeability determined from production tests in all wells is only approximately 0.5 millidarcy. This apparently indicates that the observed primary fractures do not contribute to reservoir permeability. 
Reservoir characteristics for the oil zone, averaged over the entire field, are tabulated below.

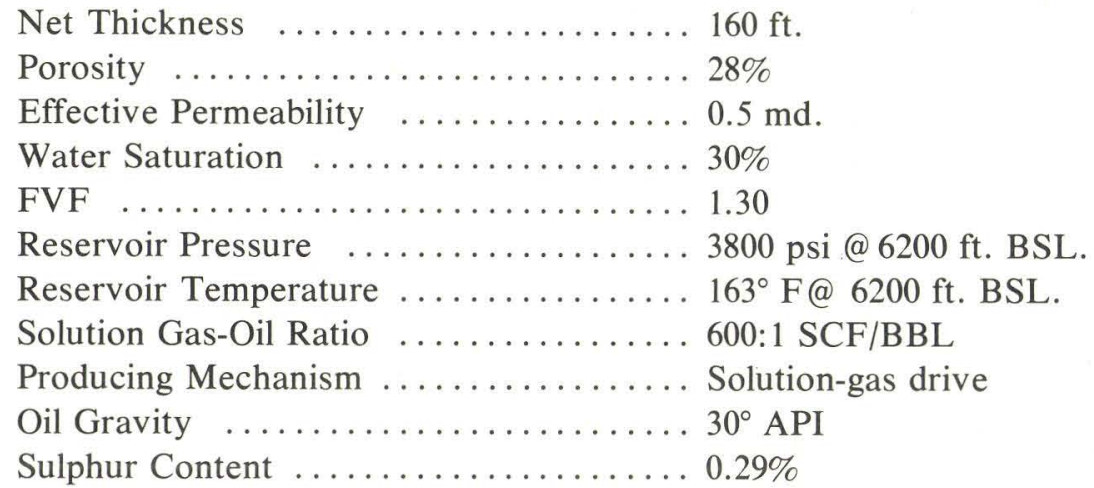

\section{Structure}

Figure 8 shows the structural configuration of the Dan field reservoir as known from well information and seismic data. The field is a symmetrical domal anticline approximately 7 kilometers in diameter. Formation dip on the flanks varies from three to five degrees.

The structure is bisected by a major NE-SW-trending normal fault with approximately 200 feet of throw down to the northwest. This fault is clearly evident in seismic profiles. Subsidiary branch faulting shown in Figure 8 represents one of several possible interpretations to account for the different levels of fluid contacts encountered in the wells. However, it is recognized that changes in capillary pressure, resulting from variations in pore size and porosity, may account equally well for the different fluid levels.

As evident from seismic reflection data, the Dan field structure is a result of halokinetic uplift which began in the Late Jurassic and continued into the Early Tertiary. Associated faulting is believed to have helped provide the paths for migration of the hydrocarbons from their Upper Jurassic source beds into the chalk reservoir.

\section{Development}

Installation of the production system was begun in mid-1971, soon after the M-2x well had confirmed the field discovery. Feasibility studies determined that the most economical production plan, designed with a maximum of safety, called for installation of a four-pile, six-well drilling platform and a four-pile production platform with associated three-pile flaring platform. It was decided to utilize an oil tanker for storage and transport of the produced oil, and therefore a Single-Buoy-Mooring loading system was installed. 


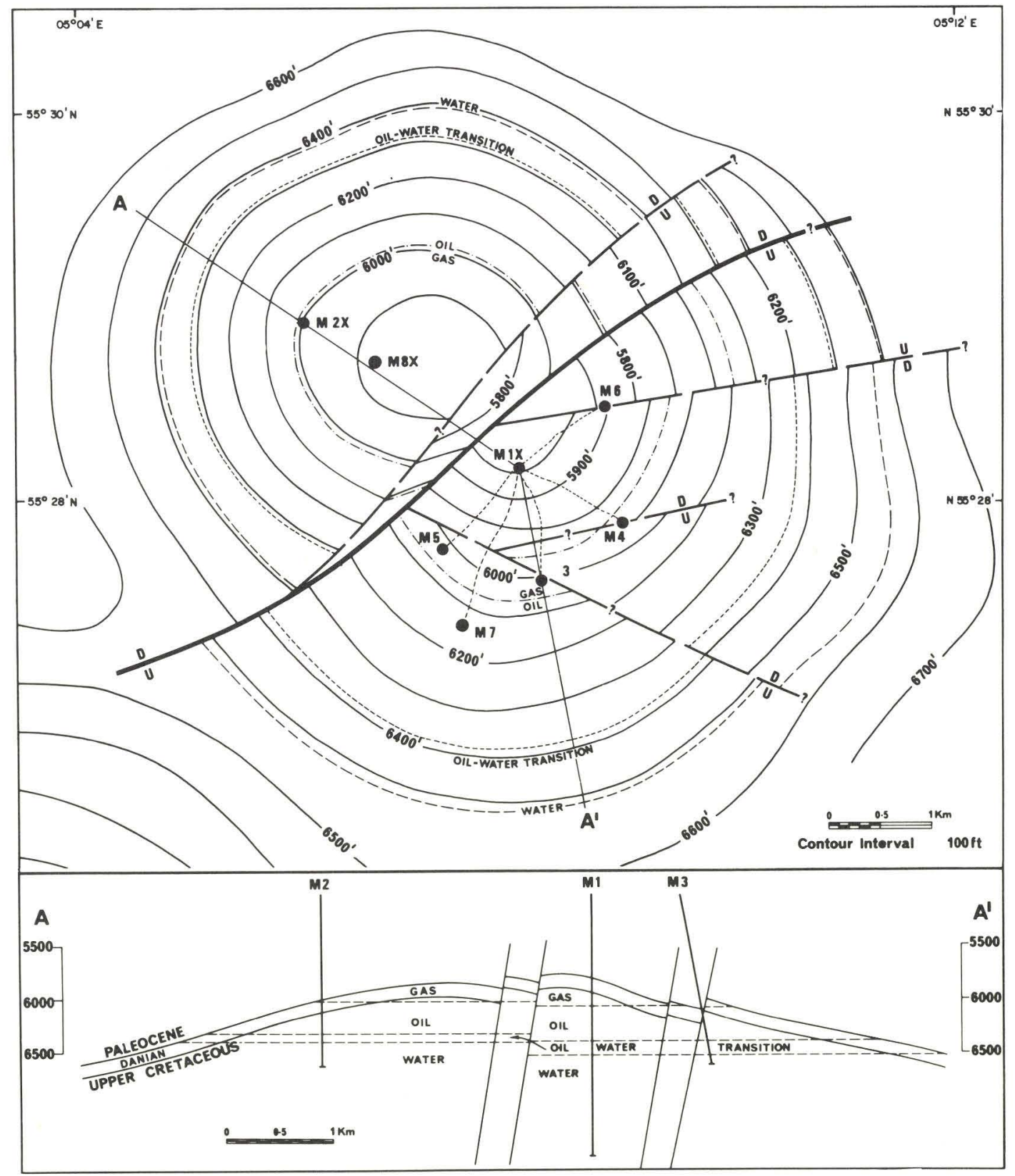

Figure 8. Structure contours on top of Danian chalk-Dan field and structural cross-section across field. 
The drilling platform and flare structure were fabricated in the United States and transported by barge to the Dan field. The drilling platform was installed in September 1971, and the drilling rig »Britannia« was moved over the platform to drill and complete four development wells. The M-1x was also re-entered and completed. Installation of the flare structure proceeded in October 1971, but was interrupted by bad weather and was resumed in early 1972.

The production platform and Single-Buoy-Mooring system were fabricated in Holland and installed after installation of the flare structure. The five wells were hooked up and production commenced on July 4, 1972. As a result of studies undertaken to determine better completion techniques, a sixth well was drilled in May 1974.

The wells are stimulated by acid-fracture treatments which have been successful in improving initial productivity. However, with the intrinsic low permeability of the chalk, each well has exhibited a decline in flow rate and tubing pressure during production. Initial production rates of each well were from 2,000 BOPD to 3,000 BOPD, but within a period of several weeks the rates had stabilized at about 800 BOPD. This decline in productivity is typical of low-permeability reservoirs.

\section{Future plans}

Since commencing production, tests have been conducted to analyze the reservoir characteristics of the chalk. The data from these tests have been used in simulation studies to ascertain the optimum completion and wellspacing procedures for development of the field. As a result of these studies, together with more favorable economic conditions, an expansion program for the development of the field is now planned.

A second drilling platform is planned for completion during the early part of 1975. The platform will be designed to accommodate six wells and will be situated adjacent to the existing production platform. This should increase the production of the field to some $8,000 \mathrm{BOPD}$, approximately twice the present production rate.

Acknowledgements. The authors express their appreciation to the companies. A. P. Møller, Shell, Chevron, Texaco and Gulf of the Dansk Undergrunds Consortium for their permission to publish this paper. Special acknowledgement is due to Gulf Oil Company of Denmark and Gulf's research and technical centers for assistance in preparation of the paper. 


\section{Dansk sammendrag}

De geologiske forhold i Dan-feltet

og den danske del af Nordsøen

Dan-feltet blev fundet i 1971 ved Dansk Undergrunds Consortiums femtende havboring, som stødte på olie og gas i kalkstensbjergarter fra maestrichtien og danien i dybdeintervallet 1899-2143 m under havoverfladen. Indvinding gennem fem boringer påbegyndtes i juli 1972 med en døgnproduktion på ca. 127000 liter olie (ca. 108 tons) fra hver boring.

Feltet ligger på den østlige flanke af det teriære Nordsøbassin og nær aksen af Central Graben «, der er et dybt trug, som indeholder en tyk serie af aflejringer fra perm til kridttiden. Kalkstensbjergarter fra $\varnothing v r e$ kridt og danien, øverst i denne lagfølge, danner reservoir for adskillige andre kulbrinteforekomster i den danske del af Nordsøen. Geokemiske studier tyder på, at moderformationen for forekomsterne sandsynligvis er dybere liggende lerskifre fra øvre jura.

Dan-feltet ligger på en antiklinal struktur, som er fremkommet ved bevægelser i underliggende saltlag.

Den gennemsnitlige porøsitet og permeabilitet i kalkreservoiret er henholdsvis $28 \%$ og 0,5 millidarcy. Forholdet mellem opløst gas og olie (GOR) er 600 cubic feet/barrel (svarende til ca. $107 \mathrm{~m}^{3}$ gas pr. $\mathrm{m}^{3}$ olie) og oliens vægtfylde er ca. $30^{\circ}$ API (svarende til 0,87 ). Svovlindholdet er lavt $(0,29 \%)$. 


\section{References cited}

Glennie, K. W. 1972: Permian Rotliegendes of Northwest Europe interpreted in light of modern desert sedimentation studies. - AAPG, 56 (6), June 1972.

Hallam, A. 1971: Mesozoic geology and opening of the North Atlantic. - Journal of Geol., 79 (2), pp. 129-157.

Heybroek, P., Haanstra, U. and Erdman, D. A. 1967: Observations on the geology of the North Sea Area. - Proc. 7th World Petroleum Congr. 2, pp. 905-916.

Sorgenfrei, T. and Buch, A. 1964: Deep tests in Denmark - Danm. geol. Unders., III række, 36, Copenhagen.

Ziegler, P. A. 1973: The North Sea in a paleogeographic framework. - North Sea petroleum geology conference, Bergen, Norway, Whiteman, A. J. and Sellevoll, M. A. 